\title{
Convergence-divergence of HRM in the Asia-Pacific: context-specific analysis and future research agenda
}

Article

Accepted Version

Creative Commons: Attribution-Noncommercial-No Derivative Works 4.0

Budhwar, P. S., Varma, A. and Patel, C. (2016) Convergencedivergence of HRM in the Asia-Pacific: context-specific analysis and future research agenda. Human Resource Management Review, 26 (4). pp. 311-326. ISSN 1053-4822 doi: https://doi.org/10.1016/j.hrmr.2016.04.004 Available at https://centaur.reading.ac.uk/68834/

It is advisable to refer to the publisher's version if you intend to cite from the work. See Guidance on citing.

To link to this article DOI: http://dx.doi.org/10.1016/j.hrmr.2016.04.004

Publisher: Elsevier

All outputs in CentAUR are protected by Intellectual Property Rights law, including copyright law. Copyright and IPR is retained by the creators or other copyright holders. Terms and conditions for use of this material are defined in the End User Agreement.

www.reading.ac.uk/centaur 
Central Archive at the University of Reading

Reading's research outputs online 


\title{
Convergence-Divergence of HRM in Asia: Context-specific Analysis and Future Research Agenda
}

\author{
* Pawan S Budhwar, PhD \\ Professor of International HRM \\ Aston Business School \\ Birmingham B4 7ET \\ UK \\ E-Mail: p.s.budhwar@aston.ac.uk \\ Arup Varma, $\mathrm{PhD}$ \\ Professor of HRM \\ Institute of Human Resources \& Industrial Relations \\ Loyola University Chicago \\ Chicago, IL 60611 \\ USA \\ E-Mail: avarma@luc.edu
}

\author{
And \\ Charmi Patel, PhD \\ Assistant Professor in HRM \\ University of Edinburgh Business School \\ Edinburgh, EH8 9JS \\ UK \\ E-Mail: Charmi.Patel@ed.ac.uk
}

\section{Paper Revised for} Special Issue of:

\section{Human Resource Management Review}

"Divergence, Convergence, or Crossvergence in International HRM"

* Corresponding Author

Acknowledgement: An earlier version of this paper was presented at the Paris Colloquium on 'HRM in Asia' in 2014. The authors thank the conference participants for their useful suggestions, which helped to improve this paper. 


\title{
Convergence-Divergence of HRM in Asia: Context-specific Analysis and Future Research Agenda
}

\begin{abstract}
Highlighting the usefulness of conducting context-specific HRM research, this article focuses on four themes. First, it highlights the need to analyze the context-specific nature of HRM in Asia in order to analyze the convergence-divergence debate. Second it presents an integrated framework, useful for conducting research in a cross-national setup and to highlight the main determinants of the dominant national HRM systems. Third, it highlights the critical challenges facing the HRM function in the Asian region. Fourth, it presents an agenda for future research in the form of research themes. While doing the above, it visits the notions of convergence-divergence of HRM in the Asian context. The analysis helps to understand the scenario of HRM in Asia, the factors responsible for it and provides guidance for future research.
\end{abstract}

Key Words: HRM, Asia, HR Challenges, Convergence-divergence, Future research

\section{Introduction}

\section{Rephrase the sentence + highlight the usefulness/contributions and structure of the}

paper To put things in context and in order to address the above raised focus of the paper, this introduction discusses issues such as why examine HRM in Asia, the need to examine the context-specific nature of HRM, and what, why and how of the convergence-divergence thesis relevant to HRM in general and for Asian region in particular. The analysis in the paper is based on secondary information. Literature on the core themes for the analysis (such as Asia, HRM in Asia, context-specific HRM, convergence-divergence debate/thesis, HR challenges in Asia 
including key economies in the region, future of HR in Asia, frameworks for conducting crossnational HRM research) was searched from a variety of datasets such as Proquest, ESBCO, and books and from the webpages of relevant journals.

The paper has two broad aims: first to highlight the need and mechanism to conduct a context-specific analysis of HRM in the Asian context, and second to set an agenda for future research and while doing so address the notions of convergence-divergence of HRM

for the region. By addressing these aims, we hope to make a number of contributions. First, we contribute to the HRM literature by providing an overview regarding the developments in the field in Asia, about the status of HRM and the key challenges faced by the same. Second, we provide an integrative framework useful for conducting cross-national HRM research and to highlight the context specific nature of HRM in a given national set-up. The framework is also useful to identify the key determinants of HRM. Third, we put forward a number of research themes along which future research can be conducted. This should help in developing relevant theory and practice for the region. The remaining paper is structured as following. After this introduction, we present details of our integrative framework. This is followed by the main challenges faced by the HR function in the region and research themes for future research. Finally, key conclusions of our analysis are presented.

\section{Why examine HRM in the Asian context?}

For the last couple of decades or so, due to a combination of economic and geo-political reasons, a number of Asian economies (excluding Japan which was already a significant global economic power), in particular from north-east, south and south-east Asia (the term Asia is used here in a more broader sense representing emerged and emerging economies from these regions of the continent such as Japan, South Korea, China, Hong Kong, Taiwan, Singapore, Malaysia, 
Thailand, Vietnam and India) have been the center of attraction of global trade and economic dominance. This is due to their ever increasing contributions towards the global economic growth (e.g., ADB - Asian Development Bank, 2015), emergence of significant emerging markets from the region (The Economist, 2011), becoming the most important destination for global foreign direct investment (UNCTAD, 2012), rapid emergence of multinational companies from emerging markets in the region (e.g., Chattopadhyay et al., 2012), a strong resilience of the region against the present/last global economic crisis, the rapidly growing centers of excellence in business and management education and research in the region (e.g., Honk Kong, Singapore and rapidly emerging management institutions in India and China), the continuous strengthening and recognition of the regional economic and trading blocs and cooperation (such as ASEAN, APEC, SAARC) and home to around $60 \%$ of the world population (for details see Horwitz \& Budhwar, 2015). The massively diverse Asian context on the one hand and the under-researched emerging/emerged economies of the region on the other hand, offer exciting avenues for research. This paper intends to make a contribution in this regard.

The above-mentioned developments have understandably enhanced the interest of management scholars to conduct research in the region and have resulted in a rapid rise in the number of publications related to it (for an overview see Benson \& Zhu, 2011; the 'Working in Asia Series' by Routledge; Zhang, 2012; Budhwar \& Varma, 2014), including an increasing number of special issues of journals (see e.g., Rowley, 1997; Warner, 2002; 2002; Ahlstron \& Bruton, 2004; De Cieri et al., 2005; Jain et al., 2012), the creation of a number of dedicated journals to the region such as Asia Pacific Business Review, Asia Pacific Journal of Management, Management and Organization Review, Asian Business and Management and Asia Pacific Journal of Human Resources, amongst others and the creation of learning societies like the Asian Academy of Management. 
Give subheading R2 - Context of IHRM Given the global dominance of Western management thought, initially majority of the research publications emerging from Asia were based in Western management constructs and theories (e.g., Hofstede, 1993; Meyer, 2006). Given the unique socio-cultural, institutional, political-legal and business context of Asian economies, research based on Western approaches prove to be less suitable in highlighting the key characteristics of the dominant management approaches in general and HRM systems in particular in the Asian context (e.g., Leung, 2012). There is then a great need to conduct contextspecific research, which can help to reveal the distinctiveness and deep logics surrounding the research phenomenon relevant for the region.

It is now established that research in contextual isolation is not only misleading, but it strongly hinders the understanding of core aspects of the research phenomenon in any significant way (Schuler et al., 2002: 41). Indeed, scholars for a while have been calling for conducting context-specific HRM research with context relevant constructs (e.g., Locke \& Thelen, 1995; Morishima, 1995; Budhwar \& Sparrow, 2002; Schuler et al., 2002; Morley, 2004; Deadrick \& Stone, 2009; Klien \& Delery, 2012). Responding to such calls, lately, scholars have initiated a move to highlight the indigenous management constructs and models (ahead of the established Western management models) more valid and suitable for specific geographical contexts (see Stone-Romero, 2008; Tung \& Aychan, 2008; Cappelli et al., 2010; Klien \& Delery, 2012). Nevertheless, such work in the Asian context is in its infancy (e.g., Zhu et al., 2007; Yeung et al., 2008; Special Issue of MOR - Leung, 2012; Khatri et al., 2012).

Also, there is still a scarcity of research focusing on the nature of dominant HRM system(s), forces determining the same, challenges faced by the HR function and the future of HRM in the Asian region (see Budhwar \& Varma, 2014). Research along such themes is known to highlight the context-specific nature of the HRM function and also contribute to the 
development of relevant policies and practices and theories of HRM (Warner, 2000; Rowley \& Benson, 2000; 2004; Budhwar \& Debrah, 2009; Rowley \& Poon, 2010). In a significant contribution to this debate, Meyer (2006) asserts that in view of the challenges facing Asian businesses, Asian researchers should focus on context-specific issues. In his view, such research should be capable of making major contributions, for instance by explaining the context-specific variables and effects, and by drawing on traditional Asian thought in developing new theories.

Indeed, a number of scholars have contributed immensely to highlight the various aspects of HRM in certain countries of the region (see Table 1 for examples of such contributions).

of Warner, 2000; 2002; Cooke, 2012; 2014 on China; Bae, 1997; Rowley \& Bae, 2014; Kim \& Bae, 2004 on South Korea; Budhwar \& Bhatnagar, 2009 on India; Conrad, 2009, Haghirian, 2010, Miyoshi \& Nakata, 2011; Bebenroth \& Kanai, 2011 on Japan; Napathorn \& Suchada, 2011 on Thailand; Vo, 2009 on Vietnam; Chew, 2005; Long \& Wan, 2008 on Malaysia; Heracleous et al., 2009 on Singapore; Nankervis et al., 2013 on China and India; Debroux et al., 2012 on Japan, Korea and Taiwan). Contributions by Siengthai et al. (2010), Benson and Zhu (2011) and Varma and Budhwar (2014) along with different volumes in the 'Working in Asia' series by Routledge (see Andrews et al., 2002; Tang \& Ward, 2002; Jackson \& Tomioka, 2003; Rowley \& Abdul-Rahman, 2007; Rowley \& Yukongdi, 2008; Rowley \& Paik, 2008; Budhwar \& Bhatnagar, 2009; Andrews \& Siengthai, 2009; Rowley \& Truong, 2010; Rowley \& Cooke, 2010; Malik \& Rowley, 2015) provide a useful overview regarding the scenario of employment relationships, industrial relations and key developments in the field of HRM in the Asian context. 
The key HRM themes along which evidence exists from such works include the dynamics of Asian labour markets, multi-dimensions of industrial relations and labour relations, a number of country specific HRM studies, women managers, research into dominance of Anglo-Saxon models, convergence-divergence, factors affecting employment relations, HRM in selected sectors (such as the business process outsourcing - BPO, knowledge based economies), HRM and performance, and diversity management.

However, given both the rapid economic developments in the region and also developments in the field of HRM, there is still scope for further HRM research with more robust methodologies (e.g., involving multi-level analysis, multi-source data, multi-methods, contextrelevant constructs and advanced levels of analysis), which can help to highlight the prevalence of indigenous and context specific HRM systems. This is further crucial, given the strong heterogeneity amongst the nations in the region, which is based on economic development, sociocultural, political and institutional differences and the influence of such context and forces on HRM policies and practices (e.g., Rowley \& Harry, 2011; Rowley \& Warner, 2011; Benson \& Zhu, 2011). There is also a clear scope for comparative analysis within the region. Perhaps, something along the lines of Cranet survey which has helped to provide a good overview regarding the scenario of HRM in a number of European nations (see Parry et al., 2011 for details about the Cranet project). Indeed, the Cranet survey results have helped to address the convergence-divergence debate in the European context (see e.g., Sparrow \& Hiltrop, 1994; Morley, 2004; Brewster \& Mayrhofer, 2012). Can such a research instrument be utilized for the Asian context? What exactly is the convergence-divergence debate? And what will be its use if addressed in the Asian HRM context? Provide a transition para R2

\section{Convergence-divergence debate}


Since early 1960s there have been theoretical arguments for both convergence and divergence. Initially (in 1950s \& 60s), there was a strong emergence of belief towards convergence based on similarity of organization, technology, operations and planning (see for example works of Dunlop, 1958; Harbison \& Meyers, 1959; Kerr et al., 1960; Galbraith, 1967; Kerr 1983). Later (starting from 1970s), cross-cultural theorists such as Hofstede (1983; 1991; 1993), Ralston et al. (1997), Turner and Windmuller (1998), and House et al. (2002); amongst others argued that due to strong differences in cultural norms and values, convergence at all levels is highly unlikely. Within the field of HRM and in particular for the comparative school of thought on international HRM (see Brewster, 2004; Budhwar et al., 2009; Dowling et al., 2013) scholars such as Brewster and associates (e.g., Brewster, 2004; Tregaskis \& Brewster, 2006; Brewster \& Mayrhofer, 2012; Brewster et al., 2015), Sparrow and colleagues (e.g., Sparrow \& Budhwar, 1997; Sparrow \& Hiltrop, 1997; Sparrow et al., 1999), Mcgaughey and De Cieri (1999), Katz and Darbishire (2000), Rowley and Benson (2000; 2002), Liu et al. (2004), Pudelko et al. (2006), Witt (2008), Paik et al. (2011), amongst others instigated work on the convergencedivergence theses.

In order to study these issues, we need to have a clear understanding of what we mean by the terms convergence, divergence and crossvergence and how best these can be examined, especially for an under-researched and extremely diverse Asian context. In a recent contribution, Guo (2015) explains the thesis of cultural convergence, divergence and crossvergence. Develop a table The convergence thesis focuses on the creation of similarity in the thinking, values, attitudes and behaviors of individuals due to an emergence of common belief system/logic, initially developed due to industrialism and then by forces such as globalization, technological developments, internationalization of businesses, cross-national diffusion of work processes, a move towards the 'best practice' model and emergence of similar trends (e.g., performance based 
systems and abolishing of life-long employment). On the other hand, the divergence thesis suggests that due to a variety of factors such as diversity of cultural value orientations, variety of capitalism, distinct national business systems, diverse and unique legal set-up, intra-national heterogeneity in case of large nations, amongst others, individuals from a nation/society will retain their specific preferences, thinking, mindsets, values, attitudes, and behaviors through time (also see Katz \& Darbishire, 2000; Brewster et al., 2015). Whereas, the thesis of crossvergence propagates that due to the dynamic and increasing interaction of global socio-cultural influences and business philosophies and ideologies, a unique value system continues to emerge in the global society (also see Ralston, 2008).

Take this above the table on C-D Linking it to the field of HRM, recently, Brewster et al. (2015) present a clear account about similarities (based on single time analysis) versus convergence (which means coming together over a period of time), directional convergence (where unit of analysis share same trends) and final convergence (implying a decrease in differences between unit of analysis). For our analysis in this paper, we revisit these phenomena to highlight the converging and diverging trends in Asian HRM. At this stage, a couple of important issues need addressing. These include why examine the convergence-divergence thesis in the Asian HRM context, and how such an analysis can be conducted?

Addressing the convergence-divergence debate in the Asian context will help to find out if HRM in the Asian economies is becoming similar as they experience economic growth and development and as the HRM function continues to evolve there. Also, it can help to figure out if HRM in these economies is becoming more like the developed countries and if some kind of 'best practice' pattern is emerging. If yes, then it might be worth finding what factors might be contributing in this regard. In the case of multinational companies (MNCs) operating in Asian economies, we have evidence of the existence of the 'best practice' model (e.g., Bjorkman \& 
Lervik, 2007; Budhwar, 2012). However, given the heterogeneity of the Asian economies, there is a strong possibility that they are maintaining difference between themselves and practice models of HRM respectively, which might be working well for them as 'good' HRM. However, in this case as well, it is critical to understand the factors contributing to the development of such distinct approach(es) to HRM in the Asian economies. In such circumstances (i.e., whether HRM is converging or diverging within Asian economies), the discovery about the key determinants of HRM in each national set-up and the region then becomes critical.

Conducting research to identify the main factors influencing national patterns of HRM will be hugely useful to both researchers and concerned policy makers to become aware of such context-specific determinants (e.g., role of national unions and labor legislation) while developing their research projects and developing relevant HRM systems. It will also help confirm that certain HRM systems of one country can be ineffective or irrelevant in other country. To reiterate the above-raised, there is a strong need to conduct context specific HRM research within the Asian region. The big question is how can researchers conduct such research? What kind of framework(s) can be adopted for the same?

\section{Framework for Cross-national Context Specific HRM Analysis}

Over the years, different scholars in the fields of comparative management, organization studies, organizational behavior and HRM have put forth a number of frameworks for conducting cross-national comparative (HRM) research. A detailed review of the same is beyond the scope of this paper. We summarize here their core emphasis. Some of the earliest frameworks were based on the 'environmental approach' proposed by Farmer and Richman (1965). For example, Murray et al. (1976) adopting this approach developed a cross-cultural comparative management research framework. Some scholars (e.g., Nath, 1988) have utilized the 'behavioral approach' to 
develop their frameworks. Here the focus has been on managerial effectiveness via cultural variables, behavioral patterns, and management philosophies. Such frameworks are operationalized via the attitude and values scales. While others (e.g., Negandhi, 1975) have adopted the 'open systems approach' to develop their frameworks. In this case the focus has been on the 'environmental forces' (i.e., organizational, task and societal) and their impact on functioning of organizations. All these frameworks present a broad list of factors and variables (though not a comprehensive one), which form the basis of cross-national comparisons.

Within the field of HRM and international HRM (IHRM) a number of frameworks have been proposed. For example, Schuler et al. (1993) developed an integrated contingency framework to examine strategic HRM (SHRM) in MNCs. In order to conduct such an examination, they identify two sets of exogenous (e.g., industry demographics and country characteristics) and endogenous factors (such as structure of MNCs' international operations), which determine the strategic emphasis of the HR function. On the other hand, Welch (1994) proposed a contingency framework for determining IHRM approaches and activities relevant for expatriate management. Her framework is based on three types of variables, i.e., contextual (e.g., cultural distance between host and parent country nationals), firm-specific (such as type of industry), and situational variables (e.g., availability of relevant staff). Along similar lines, Jackson and Schuler (1995) proposed an integrative framework to examine the 'context-specific' HRM, which emphasizes on the need to understand the impact of both internal and external contextual factors on HRM. Similar proposals have been made in some of the initial models of HRM. For example, the Matching models (see Fombrun et al., 1984) and the Contextual models (see Hendry \& Pettigrew, 1992) both emphasize on the impact of both internal and external environmental factors and variables on HRM. 
Based on a critical analysis of the existing frameworks and models in the field, Budhwar and Sparrow (2002) proposed a framework for examining cross-national HRM. They identified three levels of determinants of HRM policies and practices. These include the national level factors, contingent variables, and organizational level strategies and policies related to primary HR functions and internal labour markets (ILMs). We utilize ideas from the above-mentioned contributions as well as current trends in HRM and add our own components to develop our framework. While developing our framework we also consider the calls to examine HRM at multi levels (see Ostroff \& Bowen, 2000; Paauwe \& Boslie, 2002; Hackman, 2003; StoneRomero, 2008; Takeuchi et al., 2009) in order to conduct robust and context-specific research (also see Lazarova et al., 2014).

\section{Insert Figure 1 Here}

Figure 1 presents our integrative framework for cross-national comparative HRM analysis. It is integrative because it brings together different levels of factors and variables known to influence HRM policies and practices. It proposes three levels of analysis and accordingly three levels of determinants of HRM - macro, meso and micro. Table The macro level determinants of HRM will include society, national, international and global level factors such as national business systems (e.g., Whitley, 1992), national culture (e.g., Hofstede, 1991), different institutions (both national and international such as legislation, role of professional bodies, trading blocs such as ASEAN, the European Union), established socio-cultural traditions, dominant ILMs, different types of risks such as currency fluctuation and physical danger to life and premises, mass migration, historical developments in the HR function (e.g., Brewster, 1995; Sparrow \& Hiltrop, 1997; Budhwar \& Varma, 2014) and global competitive business 
environment (Dowling et al., 2013). The meso level determinants will include industry level factors and variables (e.g., different stakeholder such as sector specific unions, legislations, technological advancements, sector specific standards, strategic alliances, bench marking of specific practices such as compensation, challenges for the HR function, see Benson \& Zhu, 2011; Lazarova et al., 2014). The meso level determinants can act as intermediaries between the macro and micro level determinants of HRM. The micro level variables are the organizational/strategy/individual levels, which are known to influence HRM policies and practices (e.g., different organizational contingency variables such as size, age, nature, ownership of the firm, presence of the HR department, corporate strategy, nature of internal labor markets, see e.g., Jackson \& Schuler, 1995).

The list of various factors and variables proposed under the three levels of determinants of HRM in our framework is not an exhaustive one. At present, we have included those factors and variables which are established in the literature and whose association with HRM can be empirically examined. Given things are in flux regarding developments in HRM in most Asian nations, it will be helpful for researchers who intend to adopt this framework to carefully identify what other context-specific factors and variables can be put under the three levels (e.g., the role of indigenous constructs such as Guanxi on HR function or consider indigenous business groups' specific philosophy to HRM such as in keiretsus - Japan, chaebols - Korea, guanxi qiye - Taiwan and qiye jituan - China). Clarify about the levels of these constructs R1.

Considering the infancy to growth stage of HRM in many Asian countries, we believe that it will be useful and practical to initially focus on examining the influence of national factors on national patterns of HRM. As such it will also be relevant given the HR challenges we later highlight are of national/regional level. In this regard, we draw on available literature for abovementioned Asian countries for our later analysis. Similar developments have been reported (i.e., 
influence of national institutional forces on HRM) in the literature for Europe in 1990s (see Brewster, 1995; Sparrow \& Hiltrop, 1994; Morley, 2004; Parry et al., 2011). Accordingly, we aim to identify the impact of the main national factors on national patterns of HRM and HR related challenges in different Asian countries. In particular, we have looked for information along the themes of: available historical account regarding the development of the HR/personnel function in a given Asian country; the key factors determining HRM practices and policies (such as labor legislation, national business systems, national culture, competition, business environment, different institutions such as unions and educational and vocational training set-up of a country, economy, etc.), the key challenges presently faced by the HR function; and accordingly the future of HRM in the region. We believe these aspects will help to better understand the specific context within which the HR function has evolved and developing, about its background, present nature, the emerging HR challenges and all this should guide to identify the direction in which it is likely to head in future. It can also help predict trends for future practice and create research avenues. Further, it should help to draw useful cross-national comparisons regarding the scenario of HRM in different Asian countries and contribute towards the convergence-divergence debate in a meaningful manner.

Investigation based on the above-proposed framework then helps to highlight the role of specific contextual forces in determining the nature of HRM. For example, the economic environment significantly influences HRM in most Asian countries, but its impact varies from country to country. For instance, in Japan the recessionary conditions of the past decade or so is undermining traditional employment practices and precipitating changes in the system (see Wolf, 2010; Ishida \& Sato, 2011; Hirano, 2011). China, India and Vietnam have witnessed a boom in foreign direct investment since they liberalized their economies (though not at the same levels). However, the arrival of foreign firms in these economies have forced local firms, in pursuit of 
efficiency, to rationalize their HRM practices (Beresford, 2008; Vo, 2009; Budhwar \& Varma, 2011; Nankervis et al., 2013).

In the same way, the political and legal set-up of the respective countries influences HRM policies and practices in their own unique way. For example, China allows the existence of only one national union which functions strictly according to the wishes of the communist party (see Rowley \& Cooke, 2010). But, in India there are hundreds of local, regional and over ten national unions, which generally function in an adversarial way and have a solid with some political party (Saini \& Budhwar, 2014). Such role of unions has direct implications for the HR function. Similarly, research has revealed the unique influence of socio-culture context (for example, Islamic work principles in many Malaysian firms; Communist, Confucian and Buddhism principles in China, Taiwan, Japan and Vietnam) on HRM systems (see Budhwar \& Fadzil, 2000; Beresford, 2008; Collins et al., 2012; Debroux et al., 2012; Malek et al., 2014). Further, the vocational and educational set-up of a country is directly responsible for the employable skills its graduates will have. In majority of Asian countries getting new graduates with employable skills is a major issue, despite of producing a large number of graduates every year (see Duoc \& Metzger, 2007; Li, 2011; Nankervis et al., 2013). This has direct impact on the talent acquisition and management function of HR (e.g., Napier, 2005; Farndale et al. 2010; Lin 2011). In a booming economy (like that of many Asian countries) this also has serious implications on wage and salary suppression, job-hopping, and behavioral aspects such organizational commitment, intention to stay and organizational performance.

On the other hand, the mapping of historical developments about the nature of HRM provides a chronological assessment about its foundations in a given country and it also helps to make predictions about emerging trends. As an example, we summarize the developments in the HR function for the Indian context. A similar account can be drawn after an analysis and 
synthesis of existing works for countries such as Japan (see Jackson \& Tomioka, 2003; Ishida \& Sato, 2011), China (see Tang \& Ward, 2002; Rowley \& Cooke, 2010; Cooke, 2012; 2014); Thailand (see Andrews \& Siengthai, 2009; Siengthai, 2014), Vietnam (see Vo, 2009; Rowley \& Truong, 2010; Cox, 2014), Korea (Rowley \& Paik, 2008; Rowley \& Bae, 2014) and other Asian countries (see Varma \& Budhwar, 2014). Provision of detailed summaries (like the one presented below for India) on developments in HRM in other Asian countries is beyond the scope and purpose of this paper.

The below summary regarding the developments in the Indian HR function is developed from the analysis of the existing literature (e.g., Budhwar \& Bhatnagar, 2009; Saini \& Budhwar, 2014). Provide key debates \& intellectual advancement R2 The emergence of the personnel function in India is attributed to the appointment for the first time of labor welfare officers in 1920. This was supported by the earliest labor legislation in the country - the Trade Unions Act of 1926, which gave formal recognition to the workers' right to form unions. The Royal Commission of Labour 1931 recommended the appointment of labor welfare officers, and the Factories Act of 1948 made that mandatory in all factories employing 500 or more workers. Around the time when India got independence in 1947 and immediately after that a number of labor and industrial legislation were enacted which led to managing the labor legislation as an important area of activity for personnel managers. The Industrial Disputes Act 1947 formed one of the most important areas of labor legislation, which envisages a conciliation-adjudicationarbitration model of industrial disputes settlement.

In 1960s, the personnel function began to expand beyond the welfare aspect with three areas of labor welfare, industrial relations and personnel administration developing as the constituent roles for the emerging profession. In 1970s, the thrust of personnel function shifted 
towards greater organizational 'efficiency', and by 1980s it began to use and focus on terms such as organizational development and human resource development (HRD).

In 1990s and later, HRD became the main focus of the personnel function apart from the existing focus on industrial relations, especially in larger companies. The formation of "The National HRD Network" in 1985 was a landmark in the history of HR evolution in the country. The 1990s also witnessed the elevation in the status of personnel managers to the board level; though only in professionally managed organizations (Sparrow \& Budhwar, 1997). Subsequently, there has also been a massive upsurge in re-labeling the title of personnel mangers to HRD or HR managers, and personnel department as HRD or HR department.

The fast growing Indian economy of the late 1990s and 2000s created a pressure on the Indian HRM function to become more creative and innovative (see Budhwar \& Bhatnagar, 2009). Due to such changes the use of terms like talent management, employer branding, competency mapping, performance management, leadership development, alignment of HR strategy with business goals are now being talked about or are seriously implemented especially in leading private sector organizations, MNCs operating in India and also taught by leading business schools in the country (Budhwar \& Varma, 2011). Indeed, the rapidly changing business context of India is forcing such developments.

The above summary regarding the historical developments in Indian HRM helps to put things in context and along with the other macro level components of the above-presented framework (see Figure 1) helps to better understand the unique Indian socio-economic and institutional context which has contributed to the present status and nature of the HR function. Given the economic developments predicted for India, one can expect the Indian HR function to continue to evolve and play a more strategic role in firms operating in India. There is emerging evidence that this is already happening in foreign firms (see Budhwar, 2012) and specific sectors 
such as IT, software and BPO (see Malik \& Rowley, 2015). Next, we present the key challenges faced by the HR function in the Asian context and propose 'research themes' for future investigations. This is based on the analysis of the existing literature, on-going trends and predictions for the field of HRM.

\section{Challenges Facing HRM in Asia and Avenues for Future Research}

The main challenges facing the HR function in the Asian context are represented in the below presented sub-headings. We have identified these based on a through analysis of existing literature (e.g., pursuing search on various databases by looking for words like Asia, each of the above-mentioned countries representing emerged/emerging Asia, HR challenges, future of HR, way forward, and related terms; by looking for relevant information in books like the Routledge 'Work in Asia' series, and other relevant publications). We also briefly indicate how each of the below mentioned proposed research theme (presented in the form of research propositions) is linked to the 'macro' level factors of our integrative framework for cross-national HRM analysis in figure 1.

\section{Talent Acquisition, Development \& Retention}

The last decade or so has witnessed a clear shift of balance of power from North America and Europe to Asia. China is now considered a clear economic global leader with India not so far behind. High economic growth will generally need quality talent to make it happen and sustain it. Many Asian emerging markets (e.g., China, India, Malaysia, Thailand, Vietnam, amongst others), despite of producing a large number of graduates, struggle to meet their talent requirements. This is mainly due to the availability of poor quality talent on the one hand and strong demand for talent on the other (see Dickel \& Watkins, 2008; Cooke, 2014 and Budhwar \& Varma, 2011 
respectively for China and India; and Nankervis et al., 2013 for both and Horwitz \& Budhwar, 2015 for an overview). In addition to this, high demand for talent results in talent poaching and job-hopping, which creates a major challenge for the HR manager. This is further supplemented by the desire for talented candidates to work in MNCs on the one hand and the cross-national and global movement of talent on the other. For example, due to long persisting recessionary conditions in Japan, a number of Japanese professionals are getting jobs in Korean firms in Korea (e.g., Bebebroth \& Kanai, 2011; Rowley \& Bae, 2014). On the one hand this allows Korean firms to get experienced and skilled professionals, but it creates the challenge of integrating them in the main workforce and culture of the concerned firms. Linking all this to the 'macro' level factors influencing HRM in a national and cross-national context in our framework, we can see the significant role of national educational-vocational and training set-up in the creation of graduates who lack employable skills in many Asian countries. We can also see an active interplay of global and regional economic and competitive business environment in the creation of value of talent and the role of legal framework to allow employability of talent across national boundaries.

The existing evidence also suggests an enhanced emphasis on training for both the newly acquired and existing talent by firms operating in Asian countries. This is due to a combination of reasons. On the one hand, and building on the above point, many new recruits are not job-ready and on the other hand, due to the need to integrate the new recruits into the organizational culture, firms end up investing a lot in training. The challenge is not only in the form of dynamics of training (costs, nature of training, etc.), but also the danger of creating employable commodities and then getting them poached by competitors (see Lin 2011; Varma \& Budhwar, 2014).

Vietnam presents an interesting context, where the workforce has an excess supply of non-skilled and semi-skilled labour, while there is a continuing shortage of skilled labour, making it an imperative that training is provided, either in-house or externally (see Cox, 2014). 
This raises the dilemma where in-house training has to be weighed against cost-benefit concerns, external training needs to be evaluated against corporate needs and for quality. On the other hand, Singapore is an interesting case, which has seen a huge growth in the number of training consultants over the last two decades or so, yet it is not clear if they are able to support organizations appropriately (see Templer et al., 2014). While many of these training outfits and in-house training programs emphasize operational efficiencies and cost-reduction strategies, what the economy seems to really need is a different kind of skill set (e.g., innovation), given that the new economy is increasingly knowledge-based (Heracleous et al., 2009). On a different note, Thailand is facing a different, though related, problem. As technology and automation lead to restructuring of organizations and jobs, numerous individuals (especially older workers who have lower or no technology skills) are likely to be laid off or forced into retirement (see Napathron \& Suchada, 2011; Siengthai, 2014). This is also valid for both China and India and other countries pursing divestment of public sector organizations for the past couple of decades or so.

Interestingly, the strict central rule in China allows the implementation of such change programs without much trouble. Where as in India, the strong trade unions along with other political pressure groups make it very difficult to allow for such a transition (see Nankervis et al., 2013; Saini \& Budhwar, 2014). This creates a massive challenge for the HR function to restructure, downsize, and right size their organizations and also deal with demanding trade unions. This also has a significant impact on the performance of organizations, which is directly linked to a significant challenge for the HR function. Going back to the 'macro' level determinants of HRM in our framework (see Figure 1), the above presented divestment example for China and India shows how same factors, which are known to influence HRM (i.e., government policies and initiatives to pursue divestment and role of national unions) have a context-specific and unique 
(direct/indirect) impact on the HR function in different settings. Considering the above developments, we present our first set of research themes.

Research Theme 1: What are the main factors contributing to the production of poor talent in many Asian countries? What can HR managers do to attract and retain talent, what should be their strategies and why?

Research Theme 2: What are the unique forces existing in respective Asian countries that dictate an emphasis on training? Examine the linkage between demands for training; training provision, retention of talent and its impact on firm performance in Asian countries?

\section{Work-life Balance, Cronyism, and Internal Labor Markets amend the heading $\mathbf{R} \mathbf{2}$}

The growth of Asian economies has given rise to an important concern - work-life balance. In rapidly growing economies, talented employees are always in demand. Due to the worth of their talent, they are generally presented with increased opportunities to earn more which creates the danger of going overboard and ignoring family and social life in the pursuit of economic success. In fact, the impact of this is already being felt in various circles. In India, increasing numbers of applicants, especially in the IT, software and the BPO sector are seeking companies that offer work-life balance (e.g., Budhwar et al., 2009), while Korean firms are proactively addressing the issue by adopting family-friendly policies, such as designating every Wednesday as a family day, and switching all lights off at $6 \mathrm{pm}$, so employees are not tempted to work late, and instead go home to be with their families (Rowley \& Bae, 2014). The area of work-life balance is then rapidly becoming a major challenge for the HR function in the Asian 
context where emerging evidence is highlighting lots of health, psychological and social problems being experienced by staff (see Budhwar et al., 2009; Wan, 2010).

This is further aggravated by the existence of high power distance culture in the Asian societies where subordinates struggle to say no to the increased work demands of their superiors resulting in a serious work-life-imbalance. This is also linked to the traditional hierarchical social structure of many Asian countries, which has emphasized respect for superiors; they can be elders, teachers or superiors at work (see Hofstede, 1991; 1993). As a result, managers are shown to prefer centralized decision making and practice tight control and do not like to delegate authority (e.g., Debroux et al., 2012). This many a times results in the exploitation of employees who tend not to raise their voice against ill-treatment and poor management practices (e.g., Mellahi et al., 2010; Malek et al., 2014). Such set-ups generally result in organizational ineffectiveness and inefficiencies and all this creates massive challenges for the HR function. To a great extent, the above mentioned work and organizational dynamics are deep rooted into the dominant national business systems, and complex mix of socio-cultural traditions and institutional set-up of Asian societies, which are proving to be a major challenge for HR function of different Asian economies to change. Nevertheless they still exist and significantly influence most work processes (see Varma \& Budhwar, 2014). These are an integral part of the macro level factors of our integrative framework.

Further building on this, research evidence suggests that the socio-cultural and institutional set-up of Asia encourages cronyism to exist in various guises arising from different motivational bases and power dependence relations (e.g., Khatri et al., 2006). Cronyism is defined as a favoritism shown by the superior to his or her subordinate based on their relationship, rather than the latter's capability or qualification, in exchange for the latter's personal loyalty (see Khatri \& Tsang, 2003). To a great extend cronyism has been responsible for 
the last two economic crises in Asia and has adverse effect on the effectiveness and efficiency of HRM practices. While it is true that cronyism exists in every part of the world, it takes on special meaning in Asia, given the unique cultural realities of the region, whereby family oligarchies often control major chunks of the business world, while at the same time making deep inroads into the political and policy-making machinery of the country (e.g., Khatri \& Tsang, 2003; Luo, 2008). The existing literature also shows the existence of major research programs related to HRM and performance, however, there is no research, which shows the impact of cronyism on HRM and subsequently on firm performance.

At another level, HR managers face significant challenges in their attempts to utilize ILMs in Asian organizations to improve performance. It is known that ILMs make it possible for HRM practices to be consistent with a systematic and rationalized employment system (e.g., Osterman, 1994). However, in the case of Asian economies (like many other emerging markets), ILMs are generally based on social connections, political contacts, caste, religion and economic power (see Smith et al., 2012), leading to corruption at all levels - individual-organizational and national (see Leung et al., 2008). There is emerging evidence that in with the evolution of the HR function the nature and components of the above-mentioned ILMs are being challenged and instead ILMs based on performance-based systems are being developed (e.g., Conrad, 2009; Debroux et al., 2012). Nevertheless, the ILMs of Asian economies are deep rooted in their traditional societal systems and are proving a massive challenge for the HR function to modernize them. They (ILMs) are closely linked to the macro level factors of our integrative framework. Based on the above discussion, we present our next sets of research themes. 
Research Theme 3: Highlight the nature of work-life balance programs being practiced in the Asian context. How can such programs be made effective and efficient in the Asian context? What will be the challenges for HRM in this regard?

Research Theme 4: Explore the impact of cronyism on HRM efficiency and effectiveness and eventually on organizational performance in the Asian context.

Research Theme 5: Examine and highlight the emerging nature and core components of ILMs in the new economic set-up of Asian markets. How do Asian firms develop efficient ILMs to suit the modern business context in a globalized world?

\section{Unique HR Models and Intra-Country Differences}

The existing literature on HRM in Asia shows that research has been and is being conducted on a variety of topics to highlight the dominant models across different countries. These would include studies on keiretsus in Japan, chaebols in Korea, guanxi qiye in Taiwan, qiye jituan in China and Hong Kong, the traditional four pillars of management in Japan, other different aspects of Chinese management and the management models of Singapore, Chinese, Korean and Indian businesses (see Rowley \& Abdul-Rahman, 2007; Budhwar \& Debrah, 2009). However, in the present context, the validity of a number of such established ideal-typical management models is questionable (see Conrad, 2009; Capelli et al., 2010; Debroux et al., 2012). In the phase of such a transition, the HR function can play a significant role. For this to happen, it needs to be allowed to play a more strategic and change agent role. However, the lack 
of strategic emphasis allowed for the HR function in many Asian countries continues to be a major bottleneck (see Benson \& Zhu, 2011; Varma \& Budhwar 2014). There is then a need to examine and highlight the applicability of established and newly emerging business models in different Asian countries, along with the role-played by the HR function during such transition. To make the analysis more meaningful, researchers should attempt to highlight the major factors that determine HRM policies and practices in the region. To a great extend this links to the changing nature of national business systems and their impact on the national patterns of HR function; is a logical link with the macro level factors of our framework.

Related to the discussion of unique HR models in Asia is the need to understand intracountry differences. While several leading scholars (e.g., Hofstede 1993) have proposed mechanisms to understand inter-country differences, others have argued that it is critical to acknowledge that there exist substantial meaningful differences within countries (see, e.g., van Hoorn, 2014). Clearly, in the case of Asian countries, this argument is of critical importance, as China and Asia continue to be among the leaders in present and projected economic growth -- at more than 6\%, according to the BusinessWeek article looking ahead at 2015 (Nov 2014 - Jan 2015 issue). Given that more than half of the world's population lives in Asia, and that more than $35 \%$ live in China and India combine, it is critical that we move beyond general comparisons to understanding each country's unique mix of people, and the resultant demands that the mix makes on management and HR systems. Accordingly, we propose the below research themes.

Research Theme 6: What is the nature of the emerging (HR) management model(s) applicable to specific Asian countries. A related theme can be to examine the changes taking place in the historically dominant (HR) management models in countries in the region (e.g., Japan). 
Research Theme 7: Develop an understanding about the unique socio-cultural behavioral patterns and resultant needs of individuals and organizations operating in different parts of a country. Highlight the complex demands this places on HR departments to create appropriate systems, policies, and practices, that are consistent across business groups, yet address the needs of different groups satisfactorily.

\section{Managing Diverse Workforce}

Asia presents an interesting mix of workforce demographics. For example, on the one hand, India has the youngest population in the world, whereas in countries like Taiwan and Japan the average age was 43+ years in 2011 (Chang, 2014; Debroux, 2014). Such ageing population is creating major HR challenges with issues related to medical-care, retirement benefits and increase in retirement age. Along with this, the mix of different generation of employees is creating a different type of HR challenge related to meeting aspirations of employees and creation of relevant motivational and career development plans. The information provided in popular press highlights sky-high aspirations of young generation regarding both career jumps and salary increases. The loyalty and organizational commitment of such staff is significantly different to older staff that prefers stability and job security (e.g., Peng et al., 2009). Managing such diverse expectations of the workforce is proving to be a major challenge for the HR function.

There are also serious issues related to females' participation in the workforce. For example, the growth of the BPO sector in India has for the first time forced the government to amend the labor legislation to allow females work on night shifts (Saini \& Budhwar, 2014). Similarly, the females' participation in the Singaporean workforce has been steadily increasing (from $65.4 \%$ in 2001 to $75.7 \%$ in 2011). Interestingly, a large number of qualified females 
(typically in late 30s) voluntarily withdraw from the workforce to raise families (see Templer, et al., 2014). But they struggle to join back the workforce once the childcare responsibilities have become less demanding. Where as in countries like Japan, Taiwan, Hong Kong, China, Malaysia and Korea, females struggle to get to middle and senior managerial positions, despite of having the required competencies (see Rowley \& Yukongdi, 2008; Peng et al., 2009; Debroux et al., 2012). Such existence is also a strong reflection of the dominant socio-cultural and institutional set-up of Asian societies revealing a clear link with the macro level factors of our framework. Based on the above presentation, we present our next research theme.

Research Theme 8: What are the unique challenges experienced by HR to manage the diverse workforce in different Asian countries? And what are the complex forces, which are creating such challenges and how best to handle them?

\section{Western Management Approaches and Theories in Asia}

One outcome of the move of Western MNCs to Asian countries has been the transfer of their HR systems in their Asian operations (e.g., Dowling et al., 2013). In this regard, scholars have regularly looked at the challenge of application of Western management and organization theories in the Asian context (e.g., Paik et al., 2011; Rodrigues \& Child, 2003). While Pun et al. (2000) on the basis of a comparative analysis between Anglo-American and Chinese cultures, highlight the pervasive influence of Chinese cultural heritage and collective orientation on Chinese organizational life. In order to adapt to the growing global environment, these authors suggest the need to determine changes to aspects of Chinese management culture. This is a big challenge to local organizations, as due to the deep cultural and institutional differences, even the 
foreign firms operating in China find it hard to implement their headquarters' HRM practices in their Chinese subsidiaries (also see Kidd et al., 2001). Arguably, this is changing as a study by Bjorkman and Lu (1999) reveal the successful implementation of global standardized HRM practices in foreign firms operating in the Chinese context. Similarly, Budhwar's (2012) investigation also highlights the existence of a similar phenomenon in foreign firms operating in India. Such results indicate that perhaps certain level of standardization of HRM systems is taking place around the globe with local adaptations. Also, there are indications regarding the existence of a hybrid approach to people management in the Asian context (e.g., Zhu et al., 2007). This creates an interesting dilemma for the HR manager when it comes to choosing which approach to adopt to develop their HRM systems. In order to explore and understand the emerging scene, more research is need in this regard.

On the other hand, highlighting the lack of applicability of the western management approaches and theories in the Asian context, there are now regular calls to identify and develop context-specific constructs (see Tung \& Aychan, 2008; Varma \& Budhwar, 2014). In this regard, a number of China related research has been conducted over the past few years and outlets like Management and Organization Review and Asia Pacific Journal of Management have been very helpful (see for example Leung, 2012). There is emerging evidence along the same lines from India as well (see Capelli et al., 2010; Khatri et al., 2014) where the prevalence of unique indigenous management approaches and constructs are being highlighted. Such developments are encouraging and exciting and certainly a meaningful way forward (i.e., identify and highlight the country/Asia specific management/HR approaches and constructs). Indigenous constructs and approaches have a logical link with the national factors (e.g. national culture) highlighted in our framework. Based on such developments, we present our next set of research themes. 
Research Theme 9: Highlight the main factors contributing to the successful implementation or otherwise of western approaches to HRM in the Asian context.

Research Theme 10: Identify, highlight and present robust country/Asia specific HR approaches and constructs. Examine the impact of the same on organizational performance.

\section{Dated Legal Systems and Performance}

One of the issues faced by MNCs when they operate in other countries is the need to develop and implement practices and policies that are in consonance with local labor and related laws (Dowling et al., 2013). In the case of MNCs operating in Asia, this takes on special significance, as many Asian countries have been slow to update their legal systems. As a case in point, India has numerous labor laws (over 60 at the national level and over 150 at the state level) that often put a stranglehold on the economy and businesses alike (see Saini \& Budhwar, 2014). It is not surprising that India ranks 134 out of 189 countries on the World Bank's 'Ease of Doing Business', 2014. A similar scenario exists in many other Asian economies (see Siengthai et al., 2010; Benson \& Zhu, 2011). The myriad of (dated) legislation and their poor implementation have links with poor governance, corruption and subsequently on organizational and national performance. Given that the HRM scene is changing in Asia, it is critical that the relevant legislations are updated so they can be more effective and allow organizations to operate within the legal umbrella. The national legal framework of a country is central to our macro level factors in our framework. Accordingly, we present our next research theme. 
Research Theme 11: Examine and highlight the impact of dated labor legislation or organizational and national (in)effectiveness. Identify the core obstacles in the updating of labor legislation in Asian countries and what needs to be done to bring such changes.

\section{HRM in the Informal Sector}

A significant majority of the work in most Asian countries exists in the informal sector. For example, in India, out of a total workforce of approximately $400 \mathrm{mn}$, only $9 \%$ operates in the formal sector (i.e., for which there is a formal work contract, see Saini \& Budhwar, 2014). There is a scarcity of research regarding how workers are managed in the informal sector in different Asian countries and their impact on national productivity and outputs. Given that large populations of Asian nations are 'employed' in the informal sector (see Benson \& Zhu, 2011), it is critical that research is undertaken to better understand the HRM systems in the informal sector, so that we may learn from them. One of the issues often raised about the informal sector is the possibility of exploitation of those employed in this sector - yet, given that a significant majority of the workforce is provided employment by this sector, it is critical to acknowledge the role played by the informal sector in the economic growth of nations. The existence of the informal work sector in Asian nations is then an outcome of their national business and legal systems of a given country (Whitley, 1992); a link with the macro level factors of our network. Accordingly, we present our next research theme.

Research Theme 12: Examine and highlight the nature and pattern of HRM systems in the informal sector of Asian countries and their impact on performance at different levels (individual, organizational and national). 


\section{Strategic Nature of HRM}

In majority of the Asian nations, the HR function (especially in local and national firms and in small to medium size firms) is still playing a reactive role and in many cases there is no HR department in organizations or representation of HR at the board level (e.g., Varma \& Budhwar, 2014). However, as these economies continue to economically grow and become more competitive, it is critical that nature of their HR function also evolves and become more strategic. This recognition and empowerment is a major challenge and frustration for the HR function, especially when it has to rely on other actors for this to happen (e.g., thinking of key decision makers, which is linked to specific mindsets of managers of a give country, see e.g., Hofstede, 1993) apart from their own efficiency. We can see this happening in some Asian nations. For example, as countries like Taiwan have moved from being primarily agrarian economies to laborintensive, followed by technology and service-based, to knowledge and capital intensive economies (Chang, 2014), the role of HR has also evolved (Lee et al., 2010). Indeed, in response to increasing globalization and the resultant competition, Asian firms have begun to recognize the significant positive impact of HR systems on organizational performance and productivity. While there are empirical studies emerging from many Asian nations documenting the impact of Strategic HR (see evidence from various volumes in the 'Working in Asia' series referred above), the evolving role needs to be examined further, so that organizations can better create systems and policies and practices that are appropriate to their local context.

Research Theme 13: Examine the evolving strategic role of HRM in Asian firms, and the resultant impact on HR systems, policies, and practices and subsequently on organizational performance. 


\section{Conclusion}

Convergence-Divergence of HRM in Asia

In the past, researchers have attempted to examine the convergence-divergence thesis in the Asian context (e.g., Rowley, 1998; Rowley and Benson, 2002; Warner, 1998; 2002).

However, they have used the constructs of convergence-divergence in a loose sense and based on similarity in trends. Brewster et al. (2015) call this 'directional convergence'. In order to conduct a robust analysis of the convergence-divergence thesis, we need data, which is robust, and is consistently measuring the same phenomenon over a long period of time. Only then we can be in a position to talk about 'final convergence'. It is not easy to get this kind of data. One of the few examples of such a dataset is the one created by the Cranet surveys over the past three decades or so (see Parry et al., 2011 for details) involving a large number of countries (initially few and now have over 30 nations participating in it). In the case of Asia, we do not have anything like this. However, based on the above analysis about the scenario of HRM in Asia we can talk about directional convergence for which we have available information.

To avoid repetition of our above presentation, we summarize the key messages emerging here. For us the unit of analysis is country and broad HRM systems emerging in different countries. Our above conducted analysis also allows us to look at the factors contributing towards convergence-divergence, the HR challenges facing HR in the Asian countries (are they same, different or unique) and the emerging future focus of the HR (are they similar or different). Based on the macro level components of our framework presented in Figure 1 (i.e., national and international factors influencing HRM across Asian nations) we can see directional convergence in the form of same factors strongly determining both the nature of HRM and the challenges facing the HR function in the Asian context. We can also see similar trends in the evolvement of 
the HR function in different countries and movement towards formalizing of HR departments in increasing number of organizations.

From the MNCs' perspective, the implementation of global standardization of HRM practices and policies (with local adjustments) taking place in the Asian context is also an indication of soft convergence. We also have emerging evidence that some of the countryspecific HRM systems (e.g., the core pillars of Japanese management systems) are changing towards the global 'best practice' model, i.e., 'performance based systems'. To a great extent a combination of forces related to competition, fight for talent, realization the need for change by organizations and decision makers and the evidence from the success of the 'best practice' model is contributing towards directional convergence in the Asian context.

However, considering the heterogeneity (such as population, geography, economies, economic development phase, labor markets, socio-cultural, legal and political set-up, and HRM systems) in the region and context specific nature of HRM, it will not be sensible to talk about significant or 'hard or final convergence' taking place in Asia. Also, we do not have available data to conduct such an analysis. Given an increased emphasis on developing indigenous/ context specific and unique management constructs in Asia and their proven link with organizational performance, we can expect more and more clear examples of crossvergence HRM to emerge from the Asian context.

To sum-up, Asian economies have lately made a significant contribution to the world economy. With the growing business interest in the region, both academics and practitioners are interested in finding out about the kind of HRM systems appropriate for the region. The challenges facing HRM in Asia are clearly complex and daunting. Majority of these challenges have emerged due to the changes in the macro (economic) environment. Clearly, there is some indication that HRM is undergoing transformation in the region but it is unclear what the 
outcome of this transformation would be. Possibly, a hybrid system (based on a mixture of both traditional Asian characteristics and Western rationalized system) would emerge. However, it is important that any HRM system that emerges in the region should be context based. In this regard, we presented an integrative framework for analyzing the context specific nature of Asian HRM and presented a number of research themes to guide researchers to investigate issues that can further help to improve both relevant theory and practice. In order to conduct robust research analysis, it will be critical to utilize context relevant measures and robust methodologies. Researchers need to stop conducting investigations with established limitations and weaknesses in methodologies (e.g., cross-sectional analysis). Whether HRM in Asia in future will converge or diverge will depend largely on the dominance of the forces contributing to either.

\section{References}

ADB (2015) ADB sees strong growth for developing Asia in 2015 and 2016. 24 March. http://www.adb.org/news/adb-sees-strong-growth-developing-asia-2015-and-2016 (Accessed on 11 April 2015).

Ahlstrom, D., \& Bruton, G. (2004). Turnaround in Asia: Laying the foundation for understanding this unique domain. Asia Pacific Journal of Management, 21(1-2), 5-24.

Andrews, T.G., Chompusri, N., \& Baldwin, B.J. (2002) (Eds.). The changing face of multinationals in Southeast Asia. London: Routledge.

Bae, J. (1997). Beyond seniority-based systems: A paradigm shift in Korean HRM? Asia Pacific Business Review, 3(4), 82-110.

Bebenroth, R., \& Kanai, T. (2011) (Eds.). Challenges of human resources in Japan. Abingdon: Routledge.

Benson, J., \& Zhu, Y. (2011) (Eds.). The dynamics of Asian labour markets. London: Routledge.

Beresford, M. (2008). Doi Moi in review: The challenges of building market socialism in Vietnam. Journal of Contemporary Asia, 38(2), 221-243.

Bjorkman, I., \& Lervik, J.E. (2007). Transferring HR practices within multinational corporations. Human Resource Management Journal, 17(4), 320-335. 
Bjorkman, I., \& Lu, Y. (1999). The management of human resource in Chinese-Western joint ventures. Journal of World Business, 34, 306-324.

Brewster, C. (1995). Towards a European model of human resource management. Journal of International Business Studies, 26, 1-22.

Brewster, C. (2004). European perspectives on human resource management. Human Resource Management, 14(4), 365-382.

Brewster, C., \& Mayrhofer, W. (2012). Comparative human resource management: An introduction. In C. Brewster \& Mayrhofer, W. (Eds.), Handbook of comparative human resource management (pp. 1-23). Cheltenham: Edward-Elgar.

Brewster, C., Mayrhofer, W., \& Cooke, F.L. (2015). Convergence, divergence and diffusion of HRM in emerging markets. In F. Horwitz \& P. Budhwar (Eds.), Handbook of human resource management in emerging markets (pp. 451-469). Cheltenham: Edward-Elgar.

Budhwar, P. (2012). Management of human resources in foreign firms operating in India: The role of HR in country-specific headquarters. International Journal of Human Resource Management 23(12), 2514-2531.

Budhwar, P., \& Varma, P. (2014). Managing human resources in Asia-Pacific: An introduction. In A. Varma, \& P. Budhwar (Eds.), Managing human resources in Asia-Pacific (pp. 1-9). London: Routledge.

Budhwar, P., \& Varma, A. (2011). Emerging HR management trends in India and the way forward. Organizational Dynamics, 40(4), 317-325.

Budhwar, P., \& Bhatnagar, J. (2009). The changing face of people management in India. London: Routledge.

Budhwar, P., \& Debrah, Y. (2009) Future research on human resource management systems in Asia. Asia Pacific Journal of Management, 26, 197-218.

Budhwar, P., Varma, A., Malhotra, N., \& Mukherjee, A. (2009). Insights into the Indian call centre industry: Can internal marketing help tackle high employee turnover? Journal of Services Marketing, 23(5), 351-362.

Budhwar, P., \& Sparrow, P. (2002). An integrative framework for determining cross national human resource management practices. Human Resource Management Review, 12, 377-403.

Budhwar, P., \& Fadzil, K. (2000). Globalisation, economic crisis and employment practices: Lessons from a large Malaysian Islamic institution. Asia Pacific Business Review, 7(1), 171-198.

Cappelli, P., Singh, H., Singh, J., \& Useem, M. (2010) The India way: How India's top business leaders are revolutionizing management. Harvard: Harvard Publishing. 
Chang, W-J., A. (2014). Human resource management in Taiwan. In A. Varma, \& P. Budhwar (Eds.), Managing human resources in Asia-Pacific (pp. 97-125). London: Routledge.

Chattopadhyay, A., Batra, R., \& Ozsomer, A. (2012). The new emerging market multinationals. New York: McGraw Hill.

Chew, Y.T. (2005). Achieving organizational prosperity through employee motivation and retention: A comparative study of strategic HRM practices in Malaysian institutions. Research and Practice in Human Resource Management, 13(2), 87-104.

Collins, N., Zhu, Y., \& Warner, M. (2012) HRM in Asian socialist economies in transition: China, Vietnam and North Korea. In C. Brewster \& W. Mayrhofer (Eds.), Handbook of comparative human resource management (pp. 598-619). Cheltenham: Edward-Elgar.

Conrad, H. (2009). From seniority to performance principle: the evolution of pay practices in Japanese firms since the 1990s. Oxford: Oxford: University Press.

Cooke, F. (2014). Human resource management in China. In A. Varma, \& P. Budhwar (Eds.), Managing human resources in Asia-Pacific (pp. 10-30). London: Routledge.

Cooke, F. L. (2012). Human resource management in China: New trends and practices. London: Routledge.

Cox, A. (2014) Human resource management in Vietnam. In A. Varma, \& P. Budhwar (Eds.), Managing human resources in Asia-Pacific (pp. 166-190). London: Routledge.

De Cieri, H., Hutchings, K., \& Dowling, P.J. (2005). International HRM - an Asia-Pacific Focus. International Journal of Human Resource Management, 16(4), 471-474.

Deadrick, D.L., \& Stone, D.L. (2009) Emerging trends in human resource theory and research. Human Resource Management Review, 19(2), 51-.

DeBroux, P. (2014). Human resource management in Japan. In A. Varma, \& P. Budhwar (Eds.), Managing human resources in Asia-Pacific (pp. 65-81). London: Routledge.

Debroux, P., Harry, W., Hayashi, S., Jason, H.H., Jackson, K., \& Kiyomiya, T. (2012) Japan, Korea and Taiwan: Issues and trends in human resource management. In C. Brewster \& Mayrhofer, W. (Eds.), Handbook of comparative human resource management (pp. 620-643). Cheltenham: Edward-Elgar.

Dickel, T., \& Watkins, C. (2008). To remain competitive in China's tight labour market, companies must prioritize talent management and track compensation trends. China Business Review, July-August, 20-23.

Dowling, P., Festing, M. \& Engles, A. (2013). International human resource management. London: Thomson. 
Dunlop, J.T. (1958). Industrial relations systems. New York: Henry Holt

Duoc, T. Q., \& Metzger, C. (2007). Quality of business graduates in Vietnamese institutions: multiple perspectives. The Journal of Management Development, 26(7), 629.

The Economist (2011). Nipping at their heels. 22 January, p. 79.

Farmer, R.N., \& Richman, B.M. (1965). Comparative management and economic progress. Homewood, Illinois: Irwin.

Farndale, E., Scullion, H., \& Sparrow, P. (2010). The role of the corporate HR function in global talent management. Human Resource Management, 45, 161-168.

Fombrun, C. J., Tichy, N. M., \& Devanna, M. A. (1984). Strategic human resource management. New York: Wiley.

Galbraith, J. K. (1967). The new industrial state. Boston: Houghton Mifflin.

Gullién, M.F., \& Garcia-Canal, E. (2009). The American model of the multinational firm and the new multinationals from emerging economies. Academy of Management Perspectives, 23(2), 2335.

Guo, C. (2015). Cultural convergence, divergence, and crossvergence. Vol 6, International Management. Wiley \& Sons.

Hackman, J.R. (2003). Learning more by crossing levels: Evidence from airplanes, hospitals, and orchestras. Journal of Organizational Behavior, 24, 905-922.

Harbison, F., \& Meyers, C. A. (1959). Management in the industrial world. New York: McGrawHill.

Hendry, C. \& Pettigrew, A. M. (1992). Patterns of strategic change in the development of human resource management. British Journal of Management, 3, 137-156.

Heracleous, L., Wirtz, J., \& Pangarkar, N. (2009). Flying high in a competitive industry. Singapore: McGraw Hill.

Hirano, M. (2011). Diversification of employment categories in Japanese firms and its functionality. In R. Bebenroth, \& T. Kanai (Eds.), Challenges of human resources in Japan. Abingdon: Routledge.

Hofstede, G. (1983). The cultural relativity of organisational practices and theories. Journal of International Business Studies, Fall, 75-89.

Hofstede, G. (1993). Cultural constraints in management theories. Academy of Management Executive, 7 (1), 81-94. 
Hofstede, G. (1991). Culture's consequences: Software of the mind. London: McGraw-Hill Book Company.

Horwitz, F., \& Budhwar, P. (2015). Emerging markets in the global context: An introduction. In F. Horwitz \& P. Budhwar (Eds.), Handbook of HRM in emerging markets (pp. 1-16).

Cheltenham: Edward Elgar.

House, R., Javidan, M., Hanges, P. \& Dorfman, P. (2002) Understanding cultures and implicit leadership theories across the globe: an introduction to project GLOBE. Journal of World Business, 37(1), 3-10.

Ishida, M., \& Sato, A. (2011). The evolution of Japan's human resource management. In H. Miyoshi, \& Y. Nakata (Eds.), Have Japanese firms changed? Basingstoke: Palgrave Macmillan.

Jackson, K., \& Tomioka, A. (2003) (Eds.). The changing face of Japanese management. London: Routledge.

Jackson, S.E., \& Schuler, R.S. (1995). Understanding human resource management in the context of organizations and their environment. Annual Review of Psychology, 46, 237-264.

Jain, H., Budhwar, P., Varma, A., \& Venkata Ratnam, C.S. (2012). Editorial: Human resource management in the new economy in India. International Journal of Human Resource Management, $23(5), 1-5$.

Katz, H., \& Darbishire, O. (2000). Convergence-divergence: Worldwide changes in employment systems. Ithaca, NY: ILR/Cornell University Press.

Kerr, C. (1983). The future of industrial societies: Convergence or continuing diversity. Cambridge: Harvard University Press.

Kerr, C., Dunlop, J., Harbison, F., \& Myers, C. (1960). Industrialism and industrial man. Cambridge: Harvard University Press.

Khatri, N., Ojha, A.K., Budhwar, P., Srinivasan, V., \& Varma, A. (2012). Management research in India: Current state and future directions. Indian Institute of Management Bangalore Management Review, 1-12.

Khatri, N. \& Tsang, E.W.K (2003). Antecedents and consequences of cronyism in organizations. Journal of Business Ethics, 43 (4), 289-303.

Khatri, N., Tsang, E.W.K., \& Begley, T.M. (2006). Cronyism: A cross-cultural analysis. Journal of International Business Studies, 37, 61-75.

Kidd, J.B., Li, X., \& Richter, F-J. (2001) (Eds.) Advances in human resource management in Asia. Hampshire: Palgrave. 
Kim, D., \& Bae, J. (2004). Employment relations and HRM in South Korea. London: Ashgate.

Klien, H. J. \& Delery, J.E. (2012). Construct clarity in human resource management research: Introduction to the special issue. Human Resource Management Review, 22(2), 55-61.

Lazarova, M.B., Morley, M.J., \& Tyson, S. (2014) (Eds.). International human resource management: Policy and practice. London: Routledge.

Lee, F., Lee, T., \& Wu, W. (2010). The relationship between human resource management practices, business strategy and firm performance: evidence from steel industry in Taiwan. The International Journal of Human Resource Management, 21(9), 1351-1372.

Leung, K. (2012). Indigenous Chinese management research: Like it or not, we need it. Management and Organization Review, 8(1), 1-5.

Leung, T. K. P., Heung, C. S., \& Wong, Y. H. (2008). Cronyism; one possible consequence of guanxi for an insider: How to obtain and maintain it? European Journal of Marketing, 42(1/2), 23-31.

Li, Y. (2011). Family business succession - good people is difficult to find out? Business Weekly, $1235,32-34$.

Lin, S. (2011). Technology industry to get people - cottage providers to lure them away to dig to China. Business Weekly, 1227, 58-62.

Liu, S.S., Lau, C-M., \& Ngo, H-Y. (2004) Global convergence, human resource best practices and firm performance: A paradox. Management International Review, 44(2), 67-86.

Locke, R., \& Thelen, K. (1995). Apples and oranges revisited: Contextualized comparisons and the study of comparative labor politics. Politics and Society, 23, 337-367.

Long, C.S., \& Wan, K.W.I. (2008). Understanding the relationship of HR competencies and roles of Malaysian human resource professionals. European Journal of Social Sciences, 7(1), 88-103.

Luo, Y. (2008). The changing Chinese culture and business behaviour: the perspective of intertwinement between guanxi and corruption. International Business Review, 17, 188-193.

Malek, M.A., Varma, A., \& Budhwar, P. (2014). Human resource management in Malaysia. In A. Varma, \& P. Budhwar (Eds.), Managing human resources in Asia-Pacific (pp. 191-208). London: Routledge.

Malik, A., \& Rowley, C. (2015). Business models and people management in the Indian IT industry. London: Routledge.

Mcgaughey, S.L., \& De Cieri, H. (1999) Reassessment of convergence and divergence dynamics: Implications for international HRM. International Journal of Human Resource Management, 10(2), 235-250. 
Mellahi, K., Budhwar, P., \& Baibing, L. (2010). A study of the relationship between exit, voice, loyalty and neglect and commitment in India. Human Relations, 63(3), 349-369.

Meyer, K.E. (2006). Asian management research needs more self-confidence. Asia Pacific Journal of Management, 23(2), 119-137.

Morishima, M. (1995). Embedding HRM in a social context. British Journal Of Industrial Relations, 33, 617-640.

Morley, M. (2004) Contemporary debates in European human resource management: Context and content. Human Resource Management Review, 14(4), 353-364.

Murray, V.V., Jain, H.C., \& Adams, R. J. (1976). A framework for the comparative analysis of personnel administration. Academy of Management Review, 1, 47-57.

Nankervis, A.R., Cooke, F.L., Chatterjee, S.R. \& Warner, M. (2013). New models of human resource management in China and India. London: Routledge.

Napathorn, C., \& Suchada, C. (2011). Recent labor relations and collective bargaining issues in Thailand. Interdisciplinary Journal of Research in Business, 1(6), 66-81.

Napier, N. K. (2005). Knowledge transfer in Vietnam: Starts, stops, and loops. Journal of Management Psychology, 20(7), 621-636.

Nath, R. (1988) (Ed.). Comparative management a regional view. Massachusetts: Ballinger Publishing Company.

Negandhi, A.R. (1975). Comparative management and organization theory: A marriage needed. Academy of Management Journal, 18, 334-344.

Osterman, P. (1994). Internal labour markets: Theory and change. In C. Kerr \& P. D. Staudohar (Eds.), Markets and institutions (pp. 303-339). Cambridge, Massachuesetts and London: Harvard University Press.

Ostroff, C., \& Bowen, D.E. (2000). Moving HR to a higher level: HR practices and organizational effectiveness. In K.L. Klein \& S.W.J. Kozlowski (Eds.), Multilevel theory, research, and methods in organizations: Foundations, extensions, and new directions (pp. 211266). San Francisco, CA: Jossey-Bass.

Paauwe, J., \& Boselie, P. (2002). Challenging (strategic) human resource management theory. ERIM Report Series, Reference No. ERS-2002-40-ORG.

Paik, Y., Chow, I, H-S., \& Vance, C.M. (2011). Interaction effects of globalization and institutional forces on international HRM practice: Illuminating the convergence-divergence debate. Thunderbird International Business Review, 55(5), 647-659. 
Parry, E., Stavrou-Costea, E., \& Morley, M., (2011) The Cranet international research network on human resource management in retrospect and prospect, Human Resource Management Review, 21(1), 1-4.

Peng, K. Z., Ngo, H. Y., Shi, J., \& Wong , C. H. (2009). Gender differences in the work commitment of Chinese workers: An investigation of two alternative explanations. Journal of World Business, 44(3), 323-335.

Pudelko, M., Carr, C., Fink, G., \& Wentges, P. (2006) The convergence concept in cross cultural management research. International Journal of Cross Cultural Management, 6(1), 15-18.

Pun, K-F, Chin, K-S., \& Lau, H. (2000). A review of the Chinese cultural influences on Chinese enterprise management. International Journal of Management Reviews, 2(2), 325-338.

Ralston, D.A. (2008) The crossvergence perspective: Reflections and projections, Journal of International Business Studies, 39, 27-40.

Ralston, D.A., Holt, D.H., Terpstra, R.H., \& Yu, K-C. (1997). The impact of national culture and economic ideology on managerial work values: A study of the United States, Russia, Japan and China. Journal of International Business Studies, 28(1), 177-207.

Rodrigues, S., \& Child, J. (2003). Co-evolution in an institutionalized environment. Journal of Management Studies, 40(8), 2137-2162.

Rowley, C. (1997). Introduction: Comparison and perspectives on HRM in the Asia Pacific. Asia Pacific Business Review, 3(4), 1-18.

Rowley, C. (1998). Introduction: Comparison and perspectives on HRM in the Asia Pacific. In C. Rowley (Ed.), Human resource management in the Asia Pacific region (1-18). London: Frank Cass.

Rowley, C., \& Bae, J. (2014). Human resource management in South Korea. In A. Varma, \& P. Budhwar (Eds.), Managing human resources in Asia-Pacific (pp. 31-63). London: Routledge.

Rowley, C., \& Harry, W. (2011). Managing people globally: An Asian perspective. Oxford: Chandos.

Rowley, C., \& Warner, W. (2011) (Eds). Whither management in South East Asia? London: Routledge.

Rowley, C., Yoo, K.S., \& Kim, D. (2011) Labour markets in South Korea. In J. Benson, \& Y. Zhu (Eds.), The dynamics of Asian labour markets (pp. 61-82). London: Routledge.

Rowley, C., \& Cooke, F. (2010) (Eds.). The changing face of management in China. London: Routledge. 
Rowley, C., \& Poon, I. (2010). Change in Asia: Management theory and research related to human resources. Asia Pacific Business Review, 16(4), 591-606.

Rowley, C., \& Truong. Q. (2010) (Eds.). The changing face of Vietnamese management. London: Routledge.

Rowley, C., \& Siengthai, S. (2009) (Eds.). The changing face of management in Thailand. London: Routledge.

Rowley. C., \& Paik, Y. (2008) (Eds.). The changing face of Korean management. London: Routledge.

Rowley, C., \& Yukongdi, V. (2008) (Eds.). The changing face of women managers in Asia. London: Routledge.

Rowley, C. \& Abdul-Rahman, S. (2007) (Eds.). The changing face of management in south east Asia. London: Routledge.

Rowley, C., \& Saaidah, A-R. (2007). The management of human resources in Malaysia: Locallyowned companies and multinational companies. Management Revue, 18(4), 427-453.

Rowley, C., \& Warner, M. (2005). Big business in Asia. Asia Pacific Business Review, 10 (3/4), 236-253.

Rowley, C., \& Benson, J. (2004) (Eds). The management of human resources in the Asia Pacific region: Convergence reconsidered. London: Frank Cass.

Rowley, C., \& Bae, J. (2004). HRM in South Korea. In P. Budhwar (Ed.), Managing Human Resources in the Asia-Pacific (pp. 55-90). London: Routledge.

Rowley, C., \& Benson, J. (2002). Changes in Asian HRM. Asia Pacific Business Review, 9, 1-14.

Rowley, C., \& Benson, J. (2000). Convergence and divergence in Asian human resource management. California Management Review, 44(2), 90-109.

Saini, D., \& Budhwar, P. (2014). Human resource management in India. In A. Varma \& P. Budhwar (Eds.), Managing human resources in Asia-Pacific (pp. 126-149). London: Routledge.

Schuler, R.S., Budhwar, P., \& Florkowski, G.W. (2002). International human resource management: Review and critique. International Journal of Management Reviews, 4(1), 41-70.

Schuler, R.S., Dowling, P.J., \& De Ceri, H. (1993). An integrative framework of strategic international human resource management. The International Journal of Human Resource Management, 4, 717-764.

Siengthai, S. (2014). Human resource management in Thailand. In A. Varma, \& P. Budhwar (Eds.), Managing human resources in Asia-Pacific (pp. 149-165). London: Routledge. 
Siengthai, et al. (2010) (Eds.), The Multi-dimensions of industrial relations in the Asian knowledge-based economies. Oxford, UK: Chandos Publishing.

Smith, P.B., Torres, C., Leong, C-H., Budhwar, P., Achoui, M., \& Lebedeva, N. (2012). Are indigenous approaches to achieving influence in business organizations distinctive? A comparative study of guanxi, wasta, jeitinho, svyazi, and pulling strings. International Journal of Human Resource Management, 23(2), 333-348.

Sparrow, P., Schuler, R.S., \& Budhwar, P. (2009). Editors' introduction: Developments in crosscultural HRM. In P. Budhwar, R. Schuler \& P. Sparrow (Eds.), Major works in international human resource management (pp. vii-xviii). Volume 3, London: Sage.

Sparrow, P.R., Hiltrop, J.M. (1997). Redefining the field of European human resource management: A battle between national mindsets and forces of business transition. Human Resource Management, 36(2), 201-220.

Sparrow, P., \& Budhwar, P. (1997). Competition and change: Mapping the Indian HRM recipe against world-wide patterns. Journal of World Business, 32(3), 224-242.

Sparrow. P.R, \& Hiltrop, J-M. (1994). European human resource management in transition. London: Prentice-Hall.

Stone-Romero, E.F. (2008) Strategies for improving the validity and utility of research in human resource management and allied disciplines. Human Resource Management Review, 18(4), $205-$ 209.

Takeuchi, R., Chen, G., \& Lepak, D.P. (2009). Through the looking glass of a social system: Cross-level effects of high-performance work systems on employees' attitudes. Personnel Psychology, 62, 1-29.

Tang, J., \& Ward, A. (2002) (Eds.). The changing face of Chinese management. London: Routledge.

Templer, K., Wan, D., \& Khatri, N. (2014). Human resource management in Singapore. In A. Varma, \& P. Budhwar (Eds.), Managing human resources in Asia-Pacific (pp. 209-222).

London: Routledge.

Thite, M. (2015). International human resource management in multinational corporations from emerging markets. In F. Horwitz \& P. Budhwar (Eds.), Handbook of HRM in emerging markets (pp. 97-121). Cheltenham: Edward Elgar.

Thite, M., Budhwar, P., \& Wilkinson, A. (2014). Global HR roles and factors influencing their development: Evidence from emerging Indian IT services multinationals. Human Resource Management, 53(6), 921-946. 
Tregaskis, O., \& Brewster, C. (2006) Converging or diverging? A comparative analysis of trends in contingent employment practice in Europe over a decade. Journal of International Business Studies, 37(1), 11-126.

Tung, R.L., \& Aychan, Z. (2008) Key success factors and indigenous management practices in SMEs in emerging economies. Journal of World Business, 43, 381-384.

Tung, R.L., \& Varma, A. (2008). Expatriate selection and evaluation. In P.B. Smith, M.F. Peterson \& D.C. Thomas (Eds.), Handbook of cross-cultural management research (pp. 367378). London: Sage.

Turner, L., \& Windmuller, J. P. (1998). Convergence and diversity in international and comparative industrial relations. In M. F. Neufeld \& J. T. McKelvey (Eds.), Industrial relations at the dawn of the new millennium (pp. 192-208). Ithaca, NY: Cornell University Press.

UNCTAD (2012). World investment report 2012: Towards a new generation of investment policies. New York: United Nations Conference on Trade and Development.

van Hoorn, A. (2014). Differences in work values: Understanding the role of intra-versus intercountry variation. International Journal of Human Resource Management, 24, 1-19.

Varma, A., \& Budhwar, P. (2014) (Eds). Managing human resources in the Asia Pacific. London: Routledge.

Varma, A., \& Budhwar, P. (2014). HRM challenges in the Asia-Pacific: agenda for future research and policy. In A. Varma, \& P. Budhwar (Eds.), Managing human resources in AsiaPacific (pp. 281-287). London: Routledge.

Vo, A. N. (2009). The transformation of human resource management and labour relations in Vietnam. Oxford: Chandos Publishing.

Wan, D. T. W. (2010). Singapore industrial relations system in the globalization era. In S. Siengthai, et al. (Eds.), The Multi-dimensions of industrial relations in the Asian knowledgebased economies (pp. 125-140). Oxford, UK: Chandos Publishing.

Warner, M. (2000). Introduction: The Asia-Pacific HRM model revisited. International Journal of Human Resource Management, 11, 171-182.

Warner, M. (2002). Globalization, labour markets and human resources in Asia-Pacific economies: An overview. International Journal of Human Resource Management, 13, 384-398.

Welch, D. (1994). Determinants of international human resource management approaches and activities: A suggested framework. Journal of Management Studies, 31, 139-164.

Whitley, R. (1992). (Ed.). European business systems: Firms and markets in their national contexts. London: Sage Publications. 
Witt, M. (2008). Convergence 10 years on: Impact and further potential. Journal of International Business Studies, 39(1), 47-52.

Wolff, L. (2010). Lifelong employment, labor law and the lost decade: the end of a job for life in Japan. In P. Haghirian (Ed.), Innovation and change in Japanese management (pp. 77-99). Basingstoke: Palgrave Macmillan.

Working in Asia Series (Eds.). Andrews, T.G., Jackson, K., \& Rowley, C. London: Routledge. Zhang, M. (2012). The development of human resource management in China: An overview. Human Resource Management Review, 22(3), 161-164.

Zhu, Y., Rowley, C., \& Warner, M. (2007). Human resource management with Asian Characteristics: A hybrid people management system in East Asia. International Journal of Human Resource Management, 18, 44-67. 